\title{
The decision-making process in families of terminal ICU patients
}

\author{
Mayla Cosmo Monteiro' \\ Andrea Seixas Magalhães' \\ Terezinha Féres-Carneiro ${ }^{1}$ \\ Cristina Ribeiro Dantas'
}

${ }^{1}$ Pontifícia Universidade Católica do Rio de Janeiro, Rio de Janeiro, RJ

\begin{abstract}
The objective of this research is to investigate family members' perceptions as to the end-of-life decision-making process in an ICU. The authors conducted a qualitative descriptive study in which they interviewed six family members of critically ill patients admitted to the ICU of a private hospital. Five categories of analysis emerged from the examination of the material. This study will discuss two of those categories: the decision-making process and the relationship with the medical staff. The results indicate that family members were satisfied with communication with the medical staff, an important aspect for the decision-making process. Within this context, the shared model, prioritization of palliative care and identification of futile treatments prevailed, aimed at ensuring the patient's comfort and dignity at the end of life. The results also reveal the need for integration of palliative care in ICUs, particularly in end-of-life situations.

Keywords: communication in health care, medical team-family relationship, end of life, intensive care unit
\end{abstract}

O processo de tomada de decisão da família na terminalidade em UTI

\section{Resumo}

O presente estudo tem como objetivo investigar a percepção dos familiares acerca do processo de tomada de decisão na terminalidade em UTI. Realizou-se uma pesquisa descritiva de cunho qualitativo, na qual foram entrevistados seis familiares de pacientes gravemente enfermos, internados na UTI de um hospital privado. Do estudo do material emergiram cinco categorias de análise. Neste trabalho serão discutidas duas categorias: processo de tomada de decisão e relação com a equipe médica. Os resultados indicam que os familiares se mostraram satisfeitos com a comunicação com os membros da equipe de saúde, aspecto importante para o processo de tomada de decisão. Neste contexto prevaleceram o modelo compartilhado, a priorização de medidas paliativas e a identificação de medidas fúteis, a fim de garantir o conforto e a dignidade no processo de morrer do paciente. Evidenciou-se a busca de integração dos cuidados paliativos em UTI, principalmente em situações finais de vida. Palavras-chave: comunicação em saúde; relação profissional-família; terminalidade da vida; unidade de terapia intensiva

\section{Proceso de toma de decisiones de la familia al término de la vida en la UCI}

\section{Resumen}

El presente estudio tiene como objetivo investigar la percepción de los familiares sobre el proceso de toma de decisiones en el estado terminal de vida en la UCI. Se realizó una investigación descriptiva de carácter cualitativo, en la cual fueron entrevistados seis familiares de pacientes gravemente enfermos, internados en la UCI de un hospital privado. Del estudio del material surgieron cinco categorías de análisis. En este trabajo serán discutidas dos categorías: proceso de toma de decisiones y relación con el equipo médico. Los resultados indican que los familiares se mostraron satisfechos con la comunicación con los miembros del equipo de salud, aspecto importante para el proceso de toma de decisiones. En este contexto prevalecieron el modelo compartido, la priorización de medidas paliativas y la identificación de medidas inútiles, con el fin de garantizar comodidad y dignidad en el proceso de muerte del paciente. Se evidenció la búsqueda de integración de los cuidados paliativos en la UCI, principalmente en situaciones finales de vida.

Palabras clave: comunicación en salud; relación profesional-familia; término de vida; Unidad de Cuidados Intensivos

\section{Introduction}

The Intensive Care Unit (ICU) is a highly complex sector of the hospital, intended for patients in a grave or high-risk clinical situation. Intensive care team members, especially physicians, must make precise, appropriate decisions in a timely manner, generally in situations involving a high level of stress and uncertainty (Lighthall \& Vazquez-Guillamet, 2015). An essential process of human nature, decision-making is the process of analyzing the various alternatives available and choosing the course of action a person should take. The decision-making procedure extends across extremely intricate fields, capable of being investigated at different levels of complexity, from neurobiology to the applied social sciences (Siqueira-Batista et al., 2014). In the health field, clinical decision-making is a phenomenon that is essential to health care; it is defined 
as the process of choosing between patient-care alternatives, encompassing both diagnostic reasoning and clinical judgment (Stinson, 2016).

With the techno-scientific advance of medicine, and particularly with the advent of organ transplants, life's limits began to be questioned and altered. Technological progress modified the definition of death, consequently enabling critically ill patients to be kept in ICUs for long periods (Kovàcs, 2003).

Due to this fact, in many cases the final moments of ICU patients' lives came to be preceded by decisions as to withholding or withdrawing treatments considered futile or useless, i.e., those that offer no benefits in terms of maintaining or restoring the patient's life, thus ensuring well-being, promoting awareness of it and alleviating the patient's suffering; otherwise, they only lead to additional suffering (Curtis \& Vincent, 2010). Such decisions make up the assessment of Limitation of Life-Sustaining Treatment (LLST), which counteracts therapeutic futility, in an attempt to avoid painful dying processes. More recent studies reveal an increase of up to $90 \%$ in the use of LLST in ICUs (Paranhos \& Rego, 2014).

There are two main models for dealing, together with patients and their family members, with issues related to the end of life: the paternalistic model and the shared model. In the paternalistic model, which is predominant in Brazil and is common in public health care, the physician, due to possessing technical knowledge, makes the decisions and communicates them to the patient and his/her family. In the shared model, patients and family members are also involved in end-of-life-care decisions (Menezes, 2011; Biondi \& Ribeiro, 2013). In Brazil, this model tends to be implemented within the scope of palliative care or, depending on the medical team, in private health care. There also exists the possibility of integrating both decision-making models. Choosing one model or the other depends on the expectations of the physician, the patient and the family and on the relationship established between them. Employment of the paternalistic model relates both to factors of various types (social, moral, emotional and financial) and to the authority the physician wields within the hospital's overall structure; such authority is founded upon the preeminence of the physician's knowledge and technical competence, reflecting the existence of an institutionalized hierarchy of competence (Monteiro, Magalhães, Féres-Carneiro \& Machado, 2015).
Bioethics, a branch of ethics that focuses on issues related to human life and death, is an interdisciplinary field dedicated to moral conflicts in the area of human health and illness; it can thus aid health professionals in the management of conflicts that arise in end-of-life care, facilitating the decision-making process (Paranhos \& Rego, 2014). As of the 1990s, end-of-life care (i.e., the nature of such care, as well as ethical aspects) began to attract the attention of researchers. Issues such as dysthanasia, euthanasia and orthothanasia began to dominate discussions involving the end-of-life theme (Monteiro, 2017).

Dysthanasia means subjecting the patient to a slow, tense, painful death, for it is characterized by the continuance of invasive treatments in patients lacking the possibility of recovery. The advance of medical procedures such as mechanical ventilation, hemodialysis, and enteral and parenteral nutrition, among others, can favor the promotion of dysthanasia in ICUs, creating a scenario that is prone to produce conflicts between the family and the medical team. This issue's greatest difficulty is to determine whether a treatment is ordinary (obligatory to save the patient or to offer relief and control of his/her symptoms) or extraordinary (also known as futile) (Monteiro, Magalhães, Féres-Carneiro \& Machado, 2016).

Futile treatments are part of a context in which the withholding of therapeutic measures and, in some cases, sedation are confused with euthanasia, which amounts to the deliberate act of causing the patient's death, without the patient suffering, for merciful reasons. Euthanasia can only be considered when the patient voluntarily and explicitly requests it; otherwise, it is considered murder, even when it involves the mitigating circumstance of being a mercy killing. In Brazil, euthanasia is illegal (Kovàcs, 2003; Pessini, 2016).

One of the greatest challenges posed by a terminal illness is to preserve human dignity in the dying process without the patient being victimized by dysthanasia or having his life shortened as the result of euthanasia (Santana, Rigueira \& Dutra, 2010). What then appears is orthothanasia, death at the "right time," permitting the patient, who has already entered the terminal phase of his illness, and those around him to face his destiny with certain tranquility, for, from this perspective, death is not an illness to be cured, but rather something that is a part of life. Accordingly, it does not involve artificial prolongation of the dying process (Batista \& Seidl, 2011).

Psico-USF, Bragança Paulista, v. 24, n. 3, p. 437-448, jul./set. 2019 
In line with this perspective and satisfying new demands that have emerged with medical advances and with the dissemination of palliative care, Brazil's Federal Council of Medicine, in its new Code of Medical Ethics (Item XXIII), which was published in April 2010, legalized the practice of orthothanasia. Consequently, in cases of incurable and terminal illnesses, physicians must offer palliative care, without resorting to futile treatments, yet ensuring the care necessary to alleviate symptoms that cause suffering, always respecting the wishes of the patient or his/her legal representative (Moritz et al., 2011).

Palliative care is a new way of dealing with death; it depends on technical expertise and proposes a change in the power relations between those involved in the treatment. The palliative care team provides care aimed at producing a "good death" or "personalized death," viewing patients as individuals, placing emphasis on their needs, respecting their choices and fostering better quality of life during the time that remains (Menezes \& Barbosa, 2013). Such care is individualized, and its focus is not on the disease to be cured, but rather on the patient in all his/her diversity, an active, biographical individual with a right to information and full autonomy to make decisions concerning his/her treatment (Kappaun \& Gomez, 2013).

As highlighted in the literature, as of the time of admission to the ICU there is integration between palliative and curative care, aiming at providing highquality treatment for gravely ill patients. Palliative care in intensive therapy is intended for critical patients in a terminal state, when a cure is unattainable and thus ceases to be the focus of the assistance. In such situations, the primary objective is the patient's well-being, allowing the patient a dignified, peaceful death. Prioritization of palliative treatments and identification of futile measures must be established consensually by the multiprofessional team, the patient (if apt) and the family members or legal representative (Moritz et al., 2011; Moritz, Rossini \& Deicas, 2012; Gomes et al., 2014).

Nonetheless, although there are criteria for assessing the terminal condition's status, it is difficult to decide as to when the critical patient should receive fullscale palliative care, due to certain particularities related to patients who are admitted to an ICU and progress toward an illness considered terminal. Both previously healthy patients and patients who suffer from a chronic degenerative disease can experience unfavorable progress, it being up to the intensive care physician to decide when the patient no longer benefits from intensive treatment (Moritz et al., 2012).

Published studies highlight the importance of family participation in decisions regarding the limitation of life-sustaining treatment (LLST) (Nelson et al., 2010; Paranhos \& Rego, 2014; Lighthall \& Vazquez-Guillamet, 2015; Stinson, 2016). One such study points out that $85 \%$ of families would like to have the final word as to the LLST of their family member and that family members that participate in LLST-related discussions deal with the mourning process better (Paranhos \& Rego, 2014). Nonetheless, in practice, and especially in Brazil, such decisions focus on the physician's perspective, with scarce participation on the part of the family and other healthcare team members. The obstacles to family participation in decisions concerning end-of-life quality are related to flaws in physician-family communication and to the superficial nature of the physician-family relationship, principally in cases in which the physicians fail to adequately report the patient's prognosis (Santos \& Bassitt, 2011). In such a scenario, it is essential to stress that the dialogue between the family and the medical team is subject to variations, depending on the family's social status and its current values and beliefs, as well as emotions, interests involved, and the physical location (varies between countries, cities and regions), among other factors (Menezes, 2011).

The Society of Critical Care Medicine has listed family needs in end-of-life situations: being close to the patient; feeling useful to the patient; being aware of alterations in the patient's clinical status; understanding what is being done in terms of care and why; having guarantees as to the control of suffering and pain; feeling confident that the decision to limit curative treatment was appropriate; being able to express feelings and anxieties; being comforted and consoled; and discovering a meaning for the patient's death. Not only biomedical but also psychosocial and religious needs must be satisfied (Batista \& Seidl, 2011). A large part of such needs relate to communication between the family and the health care team. This issue has been thoroughly discussed in publications in the area of Intensive Therapy, for it is one of the basic pillars that support the philosophy and precepts of the humanization of ICUs (Nelson et al., 2010; Weaver, Bradley \& Brasel, 2012; Wiegand, Grant, Cheon \& Gergis, 2013).

Nevertheless, one of the greatest obstacles involved in the medical team's communication with the family relates to the difficulty associated with talking clearly and directly about prognoses and the limitation 
of treatments for fear of destroying the hopes and expectations of the patient and his family through effective communication. Schmidt, Gabarra and Gonçalves (2011) stress the importance of the psychologist as a mediator in the physician-patient-family relationship, offering emotional support and interpreting the difficulties that arise when death is imminent.

The complexity of discussing life and death has led to legalization of the decision to limit life-sustaining treatments. However, the discussion is complicated because most terminal patients lose their capacity for self-determination (Bussinguer \& Barcellos, 2013). The health care team then adopts other forms of decision making, such as Advance Healthcare Directives, which were sanctioned by Brazil's Federal Council of Medicine via Resolution No. 1995/2012. The resolution requires physicians to respect patients' wishes that were expressed in advance, guaranteeing patients the right to determine the manner in which they want to spend their final moments of life, given that new technological resources permit the adoption of potentially inappropriate treatments that prolong terminal patients' suffering without providing benefits and that such interventions could have been rejected by the patient beforehand. Loss of consciousness and loss of the capacity to make decisions and communicate them at the end of one's life cannot deprive an individual of his power to determine his life plan in advance. If the patient's directives came to be formalized, they must be respected in the same way as autonomous decisions are. In some cases, family members can provide information about preferences verbally expressed by the patient beforehand (Lima, Rego \& Siqueira-Batista, 2015; Bussinguer \& Barcellos, 2013). However, for this to be possible, it is essential that the physician converse with the patient previously concerning the progression of the illness and the possibilities of care in the case of refractory treatment, for a "conspiracy of silence" is frequently established, involving the transmission of information to family members alone. The Resolution's key point is the autonomy of the patient, the main character of his/her story and destiny. The physician's role must always be that of the conductor of the therapeutic process, and not the master of his patients' destiny (Bussinguer \& Barcellos, 2013).

Discussion as to the issue of decision making within the context of the ICU becomes indispensible, especially considering that the patient is frequently sedated and that it is thus up to the legal representative and/or family member to decide on the patient's dying process. Both healthcare team members and family members can be influenced by a series of different factors in their decision-making processes, which in turn increases the likelihood of conflicts between such individuals and of dynastic attitudes. One must ensure that the decisions are consistent, transparent and ethically justifiable, and that the physicians and families are supported in these processes (Lighthall \& Vazquez-Guillamet, 2015; Stinson, 2016). Along these lines, the present study sought to investigate ICU terminal-patients' relatives' perceptions regarding the decision-making process, thereby contributing to expanding the debate as to the importance of dialogue between the patient's family and the medical team, aiming at promoting effective communication between them and, consequently, aiding the decision-making process in the context of terminal illness.

\section{Method}

The present study is part of a broader research project aimed at investigating the repercussions of terminal illness on the families of gravely ill patients in an Intensive Care Unit (ICU). It is a qualitative descriptive study, conducted in a mid-sized hospital in Rio de Janeiro. The study enjoyed the participation of six middle-class families of terminal patients in the ICU. With respect to the patients, the following inclusion criteria were adopted: being hospitalized for over 48 hours in the ICU and having been admitted due to an advanced serious illness. Regarding family members, the criteria were as follows: being a member of the family responsible for the patient, being identified as a family caregiver by the multiprofessional team, and having been chosen by the unit's Psychological Services Center.

With ages ranging from 55 to 79 , the family members that were interviewed had the following relationship to the patients that were selected: spouse (3), child (2) and mother (1). Their predominant religion was Catholic $(80 \%)$. Both the patients and the family members were given fictitious names herein so as to protect their privacy. The patients' ages ranged between 40 and 93 , their predominant diagnoses were cancer and liver cirrhosis, and the duration of their hospitalization in the ICU varied greatly, ranging from 5 to 173 days. The duration of their respective terminal conditions was as follows: rapid death subsequent to initiating lifesupport procedures (Bernardo and Carlos); prolonged death (Denise, Edson and Filomena); and uncertain, 
delayed death due to the fact that the patient's state improved and she was released from the ICU (Alice).

We conducted semistructured interviews encompassing the following topics: perceptions as to the illness and its clinical progression; prior relationship with the patient and his/her representation in the family; perceptions as to communication with the medical team; aspects valued in the decision-making process; and conceptions regarding death and dying.

This study's chief researcher is a hospital psychologist at the institution we selected, thus facilitating our access to the participants, who were invited to participate only after the medical team had informed the families about the patients' worsening clinical condition and the imminence of death. The interviews were conducted in the hospital's Psychological Services department and were scheduled one day ahead. We employed data obtained from the family members' psychotherapy sessions, principally those related to family functioning. Standard ethical procedures were followed, i.e., signed informed consent forms and approval by the Research Ethics Committee.

In order to analyze the data we collected in the interviews, we employed the content analysis method proposed by Bardin (2011), via categories. The interviews were transcribed in their entirety and later analyzed. Based on the participants' statements, five categories of analysis emerged: perceptions as to the illness and its clinical progression; the impact of hospitalization on intensive therapy; perceptions regarding the terminal condition; the decisionmaking process; and the relationship with the medical team. In order to achieve this study's objective, we will discuss the last two categories. The remaining categories have already been discussed in previously published studies (Monteiro et al., 2015; Monteiro et al., 2016; Monteiro, Magalhães \& Machado, 2017).

\section{Results and Discussion}

\section{The Decision-Making Process}

The great importance of the family's participation in the decision to limit life-sustaining treatment is evidenced by the interviewees, corroborating the results of studies conducted by Nelson et al. (2010) and Paranhos and Rego (2014).

\begin{abstract}
"For example, if dialysis becomes necessary, we're not going to do it. It would mean endless suffering. And there's another thing: Edson is being treated with great dignity, always clean, well cared for" (Elisa, wife, age 79).

"I only ask that she won't suffer. The doctor promised me she'll get decent treatment, without suffering; he assured me that she's not in pain. And even though she's in a really grave state, our hearts are tranquil because we know all of you are doing everything you can for her. And that comforts a lot of people" (Ana, daughter, age 70).

"Everything that was done was done for her comfort. One day, the physiotherapist arrived to do breathing exercises, and I said it wasn't necessary. Mom suffered a lot with those exercises. So why do them? What good would that do besides tiring her? Nothing. That day, we had already decided we weren't going to invest further, just care for her" (Francisco, son, age 55).
\end{abstract}

We observe that the family members preferred palliative care in terminal situations. When dealing with

Table 1.

Terminal Patients' Family Members

\begin{tabular}{cccc}
\hline $\begin{array}{c}\text { Family Member } \\
\text { Identification }\end{array}$ & Relationship & $\begin{array}{c}\text { D Patient } \\
\text { Information }\end{array}$ & $\begin{array}{c}\text { Duration of ICU } \\
\text { Hospitalization }\end{array}$ \\
\hline Ana, age 70 & Danghter & Alice, age 93, widow, ischemic stroke & 45 days \\
Beatriz, age 65 & Wife & Bernardo, age 79, cancer with multiple & 5 days \\
& metastases & 10 days \\
Cristina, age 78 & Mother & Carlos, age 40, advanced lung cancer & 88 days \\
Denis, age 63 & Husband & Denise, age 63, advanced liver cirrhosis & 173 days \\
Elisa, age 79 & Wife & Edson, age 84, advanced COPD and & cachexia \\
Francisco, age 55 & Son & Filomena, age 83, advanced liver cirrhosis & 61 days
\end{tabular}


critically ill patients, it is indispensible to establish limits between providing them with the best possible quality of life and prolonging their lives. Accordingly, it is absolutely necessary to establish palliative care as a philosophy of care in the intensive therapy environment as well, which is justified by the fact that it is both the patient's right to receive it and the healthcare team's duty to provide it (Silva, Souza, Pedreira, Santos \& Faustino, 2013). Prioritization of palliative treatments and identification of futile treatments (such as hemodialysis and breathing exercises) must be determined consensually by the multiprofessional team, the patient (if apt) and the family members or legal representative (Moritz et al., 2011). In the eyes of the present study's participants, the shared decision-making model (Menezes, 2011; Biondi \& Ribeiro, 2013) was paramount.

'It's really hard to make some decisions. Recently, we went to the shopping center and she saw a lady in a wheelchair and said to me, "if I have to end up like that some day, I'd rather die.' It seems like she was foreseeing it (crying). That's why I told Dr. F. to do everything possible as long as her body responds, but I also told bim that, if he perceives that she's departing, that she just doesn't have the strength to go on, then let her go, without suffering. I just don't want her to go on like this, lifeless, because to her that's not living; it doesn't suit her. She always said she was going to throw a big party at 100 years of age. In her apartment building, everybody knows her; she's probably the most lively one of all" (Ana, daughter, age 70).

"I know everything; the assistant physicians tell me everything. Whenever there's a change they didn't expect, they call me to converse so we can redefine the treatment plan. I asked them to do everything possible because Denise and I still have a lot of living to do. She's always been my reason for living; after 44 years, we found each other again; she found me ... and I don't think it's fair to go on without her (gets emotional). And she has always responded to the treatments; she always was a fighter and she's struggling to stay alive, but I don't want to prolong her suffering either" (Denis, busband, age 63).

The above accounts reveal that decisions related to the treatment were based on the patients' prior wishes and were influenced by the patients' representations to the family. In the case of Alice, her daughter asked the physicians not to interfere with her mother's dying process, first of all because the patient was highly prone to suffer the aftereffects of a stroke and had previously stated that she did not want to spend her final days in a wheelchair; secondly, because of the patient's personality and lifestyle. In the case of Denise, her husband was not prepared to lose her a second time, given that in the past their first romantic relationship had been interrupted. Denis's request that the medical team "do everything possible" is justified by his desire to make up for the time lost separated from his loved one and by the patient's way of coping with the situation. Nonetheless, he was concerned about not causing the patient greater suffering via futile treatments. We stress that, in both cases, the patients were sedated and thus incapable of making decisions regarding the treatment, leaving it up to the family to do so. In addition to the abovementioned factors (the patient's prior wishes, representations to the family, personality and type of illness), other factors are also part of the decision-making process, such as the patient's previous quality of life and comorbidities (Gomes et al., 2014).

In the statements below, the patients were capable of participating in decisions; and their wishes, especially those related to the way they wanted to die, were respected by both the family and the medical team.

"During the moments in which she was lucid, because she suffered from encephalopathy, she would say that she couldn't take it anymore and that she didn't want a limited life for herself, that she no longer needed to do anything heroic, that she was tired [...] We decided everything, together. The physician would show us our options and we would say that we didn't want to see her suffer [...] Everybody's sad, but now we understand that doing anything beyond that would mean prolonging everyone's suffering, especially hers. That's why we're also calm, because we completely trusted the physicians and we made the best decision, based on all the information we had. And it was great that the team gave us time to think about it and discuss it in the in the family, without pressuring anybody (Francisco, son, age 55).

"Now I'm calmer; we decided to do what he was asking for. We can't turn off the devices, but he did want to remain sedated. He would ask us not to let him feel pain [...] and not wake bim up anymore. And we would become distressed, always thinking be would get better. Now we're fine, but I don't know what it'll be like when he actually dies. [... $\mathrm{He}$ was always very lucid, very intelligent, and he knew what the illness's progression would be like. And he would say that he didn't want to be intubated or anything like that; be wanted to switch it all off. So, we conversed a lot, the kids and I, and we thought it would be better for him to remain sedated. The doctor also agreed, because it got to the point that nothing else could give him back the life he had before he became ill. So, let's wait and see... now it's in God's hands" (Elisa, wife, age 79).

Psico-USF, Bragança Paulista, v. 24, n. 3, p. 437-448, jul./set. 2019 
The situation described by Francisco indicates his mother's participation, while hospitalized, in decisions concerning the treatment. Despite everyone's knowledge of the disease (liver cirrhosis caused by hepatitis C) and its progression, the patient and her family were trying to avoid its advance, living a "normal" life in spite of the disease. In the case of Edson, who had perceived his physical and emotional deterioration due to chronic obstructive pulmonary disease (COPD), he stated, while still at home, that he did not want to go to the ICU or be intubated; however, initially, his wishes were respected by neither his family nor the medical team, which was acting in accordance with the family's wishes. It was only because of the prolongation of the patient's period of hospitalization and increased suffering, which was expressed in his gaze and in fragments of his anguished speech (according to his daughters), that the family decided to consider the patient's request to be sedated and allowed to die in peace. Loss of consciousness and of the capacity to make decisions and communicate them during the final stage of life cannot deprive an individual of the right to determine his life plan in advance. In some cases, family members can provide information as to preferences verbally expressed by the patient beforehand (Bussinguer \& Barcellos, 2013).

Santos and Bassitt (2011) have observed changes in the behavior of families in relation to the end of life. When families perceive the prolongation of the terminal patient's suffering (as in the case of Edson), they begin to question their paradigms in terms of keeping the patient alive. Discussing end-of-life healthcare preferences with patients beforehand can decrease family members' weight in decisions to withhold or withdraw life-sustaining treatments.

On the other hand, it is not always possible to discuss the course of end-of-life care beforehand, especially when it involves a young patient. Intercurrences frequently occur in intensive therapy, requiring the medical team to act swiftly and precisely in order to stabilize the patient.

"He made all the choices: the physician, the hospital. I think even be didn't imagine things would get this bad, but I also don't know if he would tell me ... to spare me, I think. I really trust the medical team; they converse, explain what they're gonna do, and I accept it because I don't want my son to suffer. For two days, he struggled against being intubated [crying]. It was really sad, because be could still recognize us despite occasionally going unconscious. And when the doctor arrived and said she thought it would be best to put a tube in him, he popped his eyes wide open in disbelief, in a way he'd never done in all these days, and he gazed at me in despair. I started to cry, but then I remembered I had to give bim strength, and all I did was hold his hand and tell him everytbing would be all right [crying]. But I think he didn't believe me, because be kept on gazing at me with a suffering look (Cristina, mother, age 78).

In this case, it is important to emphasize that the medical and physiotherapy teams had attempted to stabilize Carlos's respiratory functions using noninvasive ventilation, given that he manifested great fear of being sedated and intubated. Unfortunately, it was not possible to just sedate him, for he was experiencing serious difficulty breathing. The steps taken by the physician on duty aimed at reducing the patient's suffering. With respect to decisions, we observe that Cristina readily accepted what she was told because she respected the choices her son had made beforehand (health care team, hospital). The patient also enjoyed the unlimited support of his company, a fact that comforted his mother, who also benefited from such support, both logistically (the company paid for her air fare and accommodations and placed a driver at her disposal) and emotionally (an employee was always present to help Cristina with whatever she needed).

We stress that the life-support technology available in the ICU can be a factor that hinders the family's true understanding of the patient's clinical condition. The imminence of death can be obscured by advanced life-support equipment, leading the family to set its sights on a "miracle cure." On the other hand, the medical team itself maintains the conviction that irreversible problems can be solved if all possible resources are put to use.

In order to ensure high-quality end-of-life care, several authors highlight family-centered care as an extension of patient-centered care and recommend the creation of a culture based on assessing family needs. Such care is provided in the course of hospitalization, as well as during and after the loved one's death (Weaver, Bradley \& Brasel, 2012; Wiegand et al., 2013). Studies indicate that the family's satisfaction with the care given to the patient, with the shared decision-making process and with the receipt of clear, direct and consistent information is an important factor for reducing posttraumatic stress disorder (PTSD) symptoms, depression and anxiety subsequent to the patient's demise. Despite the loss, when the family receives adequate attention, it retains positive memories of the care and comfort 
received, thus easing the mourning process (Nelson et al., 2010; Wiegand et al., 2013).

\section{Relationship with the Medical Team}

In health care, communication is considered a minimally invasive technology that is capable of, in a humanized manner, getting around the artifices existing between the physician, the patient and the family, for it is present throughout the patient-care process, also potentially easing suffering and avoiding grievances. When it occurs empathetically by way of positive affect, it promotes a good relationship between all of the actors involved and increases their co-responsibility, fostering the patients' autonomy and leading them to be active and participative in their treatment (Afonso \& Minayo, 2013). Communication with patients and their families is just as important as the medical treatment itself, especially in the ICU.

"The doctors have been wonderful. They always converse with us, and when I call, whether in the morning or at night, they treat me really well. I have nothing to complain about that. God placed this hospital in our path, because nobody liked the place she was at before. There they took too long to do the tomography, and she was passing out, and no one was able to tell us what was happening; nobody explained anything" (Ana, danghter, age 70).

"T've conversed a lot with the medical team, in a clear, objective way, always requesting plenty of information. I'm an engineer and I try to comprehend everything, the logic of everything, and I've come to understand that we've run out of options, and she has also come to understand this. The doctor has always been very clear and open with us" (Francisco, son, age 55).

From the family's standpoint, quality health care involves frank, daily, precise communication, without the use of technical jargon, yet with compassion. The family must be informed of the prognosis in order to give it time to prepare itself and say goodbye to its loved one. Empathetic, effective, affective communication with terminal patients' families also implies that physicians have both the ability to listen attentively and the time and availability to converse with family members whenever they need attention or express their doubts (Nelson et al., 2010; Santos \& Bassitt, 2011; Sleeman \& Collis, 2013).

"You know, yesterday, after visiting hours, I was worried; after I spoke with you, I just couldn't resist and I went to talk with Dr. G. (assistant physician). He took me by the arm and said, 'Come on, let's go see Denise.' You know, be cooled down my adrenaline. Now that's a real buman being. My assistant physicians call me every day" (Denis, husband, age 63).

"Dr. A. helps us a lot. He sends nightly messages to my danghter to inform us of Edson's condition. We really trust him. He receives us and is available to us at all times" (Elisa, wife, age 79).

The care and support provided by the assistant physicians was fundamental for the interviewed families to be able to prepare themselves for their family member's death, despite it being a hard, painful, sad experience. The hospital in which the study was conducted exhibits a unique characteristic in relation to patient hospitalization: Patients can only be admitted if they have an assistant physician (AP) who will be responsible for the entire hospitalization process, from the time of admission to the time of discharge. In addition to supervising clinical matters (i.e., deciding on the treatment and the therapeutic procedures), the AP is also responsible for conversing with the patient and the family regarding the diagnosis, prognosis, necessary procedures, and intercurrences. The ICU's staff physician is responsible for monitoring patients daily and ensuring the continuity of each patient's care plan; and the physician on duty works in shifts and has the specific task of controlling acute alterations in the clinical condition of patients that are under his constant observation, especially in cases of life-threatening intercurrences.

In a study conducted by Nelson et al. (2010), critically ill patients and family members who had gone through the ICU experience for at least five days were asked to describe high-quality palliative care. The results indicated four main areas: communication, patient-centered decision making, clinical patient care, and family care. The participants emphasized the importance of having a team leader to orchestrate the decision-making process and thus avoid confusing information, and the importance of the healthcare team's appreciation of their emotional, practical and spiritual needs.

Other studies (Santos \& Bassitt, 2011; Sleeman \& Collis, 2013) have revealed the importance of developing physicians' capacity and competence to engage in empathetic, effective and affective communication with terminal patients' families, such as appropriately providing clear, honest, realistic information in a compassionate, supportive manner; having a keen ability to listen attentively; respecting the feelings and emotional states evoked by such situations; avoiding excessive 
use of technical terms and medical jargon; and having time and availability to converse with family members whenever they need attention or express doubts. Furthermore, it is essential to respect the family's period of adaptation in this process.

Nevertheless, several interviewees reported perceiving that the communication was unsatisfactory due to the physicians' lack of clarity, objectivity and emotional preparedness.

"The doctor was vague; she could've told us that he had metastasis; it wasn't fair for us to discover everything all at once here in the ICU" (Beatriz, wife, age 65).

Having to convey "bad news" evokes fear, discomfort, impotence and frustration in physicians, feelings that are normally silenced and rarely shared with other members of the medical team. Communication requires physicians to have abilities that were neither addressed nor developed during their years of study (Afonso \& Minayo, 2013).

'I think there's a lack of training for these people to have the same objective, you know? They just obey rules. There's no respect for the family's pain, suffering or love. From the standpoint of both the nursing attendants and the physicians on duty, who are usually young and unprepared, whoever's outside the ICU doors doesn't exist. I'm not talking about technical competence because I'm not even capable of assessing that, but in relation to personal treatment, consideration, there's none here in this hospital. Very few of these people are friendly. You see, one day I got upset. Denise had just been transferred to another bed in the ICU, and she was crying, calling me. So I went back in and a doctor said, 'You can't stay in bere while we're installing the patient.' So I said, 'I just want to calm down my wife; I'll leave soon; I won't stay here. I respect your work, but please do respect my concern, my wife's pain, and mine, too.' And the doctor kept on insisting, and I said, 'You're inbuman.' And he replied, 'Don't forget we already saved your wife's life once.' He did notbing beyond his duty, you know? [...] Now, hearing a doctor on duty, who is an orangutan dressed up as a doctor, say what he said... On-duty doctors need to stop labeling themselves as demigods" (Denis, busband, age 63).

Denis made various hostile, aggressive complaints related to the physicians on duty. We also observe, during the treatments, conflicts that arose in the dayto-day routine of his wife's hospitalization. A warlike atmosphere was created, for the doctors on duty also reacted to his provocations, at times verbally, or isolating themselves and thus obstructing all attempts to approach them. As is stressed in the literature, health care teams lack proper training, especially doctors
(Santos \& Bassitt, 2011; Afonso \& Minayo, 2013; Monteiro et al., 2015).

Most intensive-care physicians are very young people, recent graduates that overvalue procedures and rules, to the detriment of relationships. They frequently report feeling unprepared to face death and dying. Such professionals are skilled to handle critical patients and they employ sophisticated technological resources, enjoying a certain amount of prestige and power alongside other medical specialists due to their superior knowledge in relation to treating critical patients. Nonetheless, their stances can fluctuate between two extremes, ranging from omnipotence to the limits of human frailty, when they come face to face with their lack of experience (Monteiro et al., 2016). The omnipotence of doctors, which is highlighted in the interviewee's account, is reflected in the process of social and institutional mystification of the figure of the doctor as a savior and a "master over life and death" (Santos, Aoki \& Cardoso, 2013).

\section{Final Considerations}

In intensive therapy, end-of-life situations are multifaceted, encompassing clinical, psychosocial, ethical, bioethical, legal and financial factors related to the use of technology in such an environment. Overall, the good doctor-family communication reported by the interviewees benefitted the decision-making process, in which the shared model prevailed. The major decisions were related to prioritizing palliative care and identifying futile treatments, aiming at ensuring the comfort and dignity of the patient's dying process. Such decisions were based on the supposition of the patient's previously expressed wishes, as well as on the wishes expressed by the patient during hospitalization. We observed that the patient's participation in the decisionmaking process was valued; after all, this process is responsible for decisions regarding the life and death of the patient. The study also revealed that the institution where the research was conducted follows the current trend, which recommends the integration of palliative care into critical care in ICUs, especially in end-of-life situations, in which the focus must center on the patient's well-being, the promotion of a dignified death and the avoidance of futile treatments, based on the family's consensus.

End-of-life decisions in the ICU are complex and are not limited to technical choices alone; they entail a relational network that involves physicians and 
healthcare team members, with their specific knowledge in each area, and patients and their families, with their own unique biographies, identities, wishes and preferences. Such a singular convergence makes end-of-life care highly variable due to the countless differences and peculiarities of each situation and of each relationship that is formed. In such a scenario, we stress the importance, in the ICU team, of the hospital psychologist, who is responsible for, among other tasks, facilitating communication between members of the patient-family-team triad, thus making room for the expression of anxieties related to the emotional wear and tear that exists in the intensive care environment.

Due to such complexity, we emphasize the need for future studies that consider the multiplicity of knowledge involved in end-of-life situations, aiming at understanding the manner in which the healthcare team and the patient and his family manage the decisionmaking process in such situations. We also recommend future studies involving different socioeconomic and cultural contexts, given that the present study was conducted with upper middle-class participants alone, which is one of the study's limitations. Another limitation is the heterogeneity of the participants' relationships to the patients (spouse, child, mother). We thus recommend studies that focus on a specific relationship to the patient.

\section{References}

Afonso, S.B.C., \& Minayo, M.C.S. (2013). Notícias difíceis e o posicionamento dos oncopediatras: revisão bibliográfica. Ciência \& Saúde Coletiva, 18(9), 2747-2756. http://dx.doi. org/10.1590/S1413-81232013000900030.

Bardin, L. (2011). Análise de conteúdo. São Paulo: Edições 70.

Batista, K.T., \& Seidl, E.M. F. (2011). Estudo acerca de decisões éticas na terminalidade da vida em unidade de terapia intensiva. Comunicação em Ciências da Saúde, 22(1), 51-60. Recuperado de: http://bvsms. saude.gov.br/bvs/periodicos/revista_ESCS_v22_ n1_a08_estudo_acerca_decisoes_eticas.pdf

Biondi, R. S., \& Ribeiro, R. A. B. (2013). A terminalidade e o tratamento fútil em medicina intensiva. Em: P. C. P. Souza \& M. F. Knibel (Orgs.). Gestão, qualidade e segurança em UTI (pp. 269-279). São Paulo: Atheneu.

Bussinguer, E. C. A., \& Barcellos, I. A. (2013). O direito de viver a própria morte e sua constitucionalidade.
Ciência \& Saúde Coletiva, 18(9), 2691-8. http:// dx.doi.org/10.1590/S1413-81232013000900024.

Curtis, J. R., \& Vincent, J. L. (2010). Ethics and end-of-life care for adults in the intensive care unit. Lancet, 375, 1347-1353. doi: 10.1016/S0140-6736(10)60143-2.

Gomes, H.A., Almeida, M.A., Matoso, T.V.F, Viana, M.A.A., Rezende, M.B.C., Bento, M.A.B., ... Dumont, P.C.P. (2014). Limitação de esforço terapêutico na pessoa com lesão encefálica grave. Revista Bioética, 22(2), 282-90. http://dx.doi. org/10.1590/1983-80422014222009.

Kappaun, N. R. C., \& Gomez, C. M. O trabalho de cuidar de pacientes terminais com câncer. Ciência \& Saúde Coletiva, 18(9), 2549-2557. http://dx.doi. org/10.1590/S1413-81232013000900009.

Kovàcs, M. J. (2003). Bioética nas questões da vida e da morte. Psicologia USP, 14(2), 115-167. http:// dx.doi.org/10.1590/S0103-65642003000200008.

Lighthall, G.K., \& Vazquez-Guillamet, C. (2015). Understanding decision making in critical care. Clinical Medicine Research, 13(3-4), 156-168. doi:10.3121/ cmr.2015.1289.

Lima, M.L.F., Rego, S.T.A., \& Siqueira-Batista, R. (2015). Processo de tomada de decisão nos cuidados de fim de vida. Revista Bioética, 23(1), 31-9. http:// dx.doi.org/10.1590/1983-80422015231043.

Menezes, R. A. (2011). Tomadas de decisão, poder médico e sentimentos no último período de vida. Em F.S. Santos (Ed.), Cuidados paliativos: diretrizes, humanização e alivio dos sintomas (pp. 193-200). São Paulo: Atheneu.

Menezes, R. A., \& Barbosa, P. C. (2013). A construção da "boa morte" em diferentes etapas da vida: reflexões em torno do ideário paliativista para adultos e crianças. Ciência \& Saúde Coletiva, 18(9), 2653-2662. http://dx.doi. org/10.1590/S1413-81232013000900020.

Monteiro, M. C. (2017). A morte e o morrer em UTI - familia e equipe médica em cena (1 ${ }^{\text {a }}$. ed.). Curitiba: Editora Appris.

Monteiro, M. C., Magalhães, A. S., Féres-Carneiro, T., \& Machado, R. N. (2015). A relação médico-família diante da terminalidade em UTI. Psicologia Argumento, 33(81), 314-329. Recuperado de: http://www2.pucpr.br/reol/pb/index.php/ $\mathrm{pa} \cdot \mathrm{dd} 1=16202 \& \mathrm{dd} 99=$ view $\& \mathrm{dd} 98=\mathrm{pb}$.

Psico-USF, Bragança Paulista, v. 24, n. 3, p. 437-448, jul./set. 2019 
Monteiro, M. C., Magalhães, A. S., Féres-Carneiro, T., \& Machado, R. N. (2016). Terminalidade em UTI: as dimensões éticas e emocionais do cuidado do médico intensivista. Psicologia em Estudo, 21(1), 6575. doi: $10.4025 /$ psicolestud.v21i1.28480.

Monteiro, M. C., Magalhães, A. S., \& Machado, R. N. (2017). A morte em cena na UTI: a família diante da terminalidade. Temas em Psicologia, 25, 13011315. http://dx.doi.org/10.9788/TP2017.3-17Pt

Moritz, R. D., Deicas, A., Capalbo, M., Forte, D.N., Kretzer, L.P., Lago, P., ... Ropelato, R. (2011). II Fórum do "Grupo de Estudos do Fim da Vida do Cone Sul": definições, recomendações e ações integradas para cuidados paliativos na unidade de terapia intensiva de adultos e pediátrica. Revista Brasileira de Terapia Intensiva, 23(1), 24-9. http:// dx.doi.org/10.1590/S0103-507X2011000100005.

Moritz, R. D., Rossini, J. P. \& Deicas, A. (2012). Cuidados paliativos na UTI: definições e aspectos éticos-legais. Em R.D. Moritz (Org.), Cuidados Paliativos nas unidades de terapia intensiva (pp. 19-31). São Paulo: Atheneu.

Nelson, J. E., Puntillo, K.A., Pronovost, P.J., Walker, A.S., McAdam, J.L., Ilaoa, D., \& Penrod, J. (2010). In their own words: patients and families define high-quality palliative care in the intensive care unit. Critical Care Medicine, 38(3), 808-818. Recuperado de: https://www.ncbi.nlm.nih.gov/pmc/ articles/PMC3267550/.

Paranhos, G. K., \& Rego, S. (2014). Limitação do suporte de vida pediátrico: argumentações éticas. Revista Bioética, 22(3), 519-528. Recuperado de: http://revistabioetica.cfm.org.br/index.php/ revista_bioetica/article/view/958/1134.

Pessini, L. (2016). Vida e morte na UTI: a ética no fio da navalha. Rev. Bioética, 24 (1), 54-63. Recuperado de: http://revistabioetica.cfm.org.br/index.php/ revista_bioetica/article/viewFile/1190/1435.

Santana, J. C. B., Rigueira, A. C. M., \& Dutra, B. S. (2010). Distanásia: reflexões sobre até quando prolongar a vida em uma Unidade de Terapia Intensiva na percepção dos enfermeiros. Revista Bioethikos, 4(4), 402-411. http://dx.doi. org/10.1590/1983-80422014223035.

Santos, M. A., Aoki, F. C. O. S., \& Oliveira-Cardoso, E. A. (2013). Significado da morte para médicos frente à situação de terminalidade de pacientes submetidos ao Transplante de Medula Óssea. Ciência \& Saúde Coletiva, 18(9), 2625-2634. http:// dx.doi.org/10.1590/S1413-81232013000900017.

Santos, M. F. G. S., \& Bassitt, D. P. Terminalidade da vida em terapia intensiva: posicionamento dos familiares sobre ortotanásia. (2011). Revista Brasileira de Terapia Intensiva, 23 (4), 448-454. http://dx.doi. org/10.1590/S0103-507X2011000400009.

Schmidt, B., Gabarra, L. M., \& Gonçalves, J. R. (2011). Intervenção psicológica em terminalidade e morte: relato de experiência. Paideia, 21(50), 423-430. http://dx.doi.org/10.1590/ S0103-863X2011000300015.

Silva, C. F., Souza, D.M., Pedreira, L.C., Santos, M.R., \& Faustino, T.N. (2013). Concepções da equipe multiprofissional sobre a implementação dos cuidados paliativos na unidade de terapia intensiva. Ciência \& Saúde Coletiva, 18 (9), 2597-2604. http://dx.doi. org/10.1590/S1413-81232013000900014.

Siqueira-Batista, R., Gomes, A. P., Maia, P. M., Costa, I. T., Paiva, A. O., \& Cerqueira, F. R. (2014). Modelos de tomada de decisão em bioética clínica: apontamentos para a abordagem computacional. Revista Bioética, 22(3), 456-61. Recuperado de: http:/ /www. scielo.br/pdf/bioet/v22n3/v22n3a09.pdf.

Sleeman, K. E., \& Collis, E. (2013). Caring for a dying patient in hospital. British Medical Journal, 346, $2174-$ 2182. doi: https://doi.org/10.1136/bmj.f2174.

Stinson, K. J. (2016). Benner's famework and clinical decision-making in the critical care environment. Nursing Science Quarterly, 30 (1), 52-57. https://doi. org/10.1177/0894318416680536.

Weaver, J. L., Bradley, C. T., \& Brasel, K. J. (2012). Family engagement regarding the critically ill patient. Surgical Clinics of North America, 92(6), 1637-47. Recuperado de: http://gsresidency.surgery.med.ubc. ca/files/2014/01/Weaver_Bradley_Brasel_Upper-GI.pdf.

Wiegand, D.L., Grant, M.S., Cheon, J., \& Gergis, M.A. (2013). Family-centered end-of-life care in the ICU. Journal of Gerontology Nursing, 39(8), 60-8. https:/ / doi.org/10.3928/00989134-20130530-04.

Recebido em: 09/04/2018 Reformulado em: 04/09/2018 Aprovado em: 28/09/2018 
Sobre as autoras:

Mayla Cosmo Monteiro. Postdoctoral student in Clinical Psychology (Pontifical Catholic University of Rio de Janeiro / FAPERJ). PhD in Clinical Psychology from PUC-Rio. Coordinator of the Lato Sensu Graduate Course in Hospital and Health Psychology at PUC-Rio.

ORCID: https://orcid.org/0000-0003-3561-278X

E-mail:mayla.cosmo@uol.com.br

Andrea Seixas Magalhães. Associate Professor at the Pontifical Catholic University of Rio de Janeiro. PhD in Clinical Psychology from PUC-Rio. Professor of Lato Sensu Graduate Course in Family and Couple Psychotherapy at PUC-Rio.

ORCID: https://orcid.org/0000-0003-2992-9844

E-mail: andreasm@puc-rio.br

Terezinha Féres-Carneiro. Full Professor in the Department of Psychology at the Pontifical Catholic University of Rio de Janeiro. Coordinator of the Lato Sensu Graduate Course in Family and Couple Psychotherapy at PUC-Rio. ORCID: https://orcid.org/0000-0002-0564-7810

E-mail: teferca@puc-rio.br

Cristina Ribeiro Dantas. Postdoctoral student in Clinical Psychology (Pontifical Catholic University of Rio de Janeiro / FAPERJ). PhD in Clinical Psychology from PUC-Rio. Professor of the Lato Sensu Graduate Course in Family and Couple Psychotherapy at PUC-Rio.

ORCID: https://orcid.org/0000-0003-0758-2093

E-mail: c.r.dantas@hotmail.com

Contato com as autoras:

Department of Psychology (PUC-Rio)

Rua Marquês de São Vicente, 225 / 201L - Gávea

Rio de Janeiro-RJ, Brazil

CEP: 22453-900 